\title{
FORMING ANALYSIS OF CONTINUOSLY ANNEALED, DOUBLE REDUCED STEEL SHEETS
}

\author{
Emil Spišák', Janka Majerníková', Peter Mulidrán', Luuboš Kaščák', Ján Slota' \\ 1 Technical University of Košice, Faculty of Mechanical Engineering, Mäsiarska 74, 04001 Košice, Slovakia, \\ e-mail: emil.spisak@tuke.sk, janka.majernikova@tuke.sk, peter.mulidran@tuke.sk, lubos.kascak@tuke.sk, jan. \\ slota@tuke.sk
}

Received: 2018.06 .27

Accepted: 2018.08.01

Published: 2018.09.01

\begin{abstract}
The paper deals with the forming analysis of continuously annealed steel sheets double reduced. Six different metal sheet grades were evaluated in the paper, thickness was in the range from 0.15 to $0.175 \mathrm{~mm}$. Described are the used methods and the results obtained by a uniaxial tensile test, biaxial test (bulge test) and a springback test.
\end{abstract}

Keywords: forming analysis, springback, packaging steel.

\section{INTRODUCTION}

The production of thin sheets has undergone significant changes over the years. These changes include, in particular, a significant change in the thickness of the packaging sheets from the original thickness from $0.24-0.22 \mathrm{~mm}$ to a thickness of $0.14-0.16 \mathrm{~mm}$. These thicknesses are achieved by introducing a second reduction. In the case of such packaging sheets, higher strength properties, in particular the Yield strength, are achieved with sufficient (for further processing by forming) plastic properties. In view of the significant changes in production of packaging steel sheets and the increasing requirements for determining their properties, it is also necessary in the area of their evaluation to seek objective, rapid and cost-effective test methods to determine their mechanical and plastic properties. Due to the fact that many different methods of mechanical properties evaluation are used by the sheet metal manufacturers and processors, the results of the mechanical properties determined by the uniaxial test, the biaxial test (bulge test) and the springback test are compared in this paper. In the paper, sheets produced by the second reduction, continuously annealed will be compared.

The results should lead to the optimization of the test method for determining the objective mechani- cal properties of the sheets and thus to create the conditions for their trouble-free processing by drawing.

\section{MATERIALS USED IN EXPERIMENT}

For experimental research of the formability of continuously annealed sheets, continuous annealed materials of different thicknesses and different melts were used. In total, 6 types of two kinds of TH $550 \mathrm{CA}$, TH $620 \mathrm{CA}$ sheets, 0.15 to $0.175 \mathrm{~mm}$ thickness (Table 1) were used.

\section{UNIAXIAL TENSILE TEST}

It is currently the most widely used test that acquires the basic mechanical properties of the sheet metal. The test conditions and shape

Table 1. Materials used in experiment

\begin{tabular}{|c|c|c|}
\hline \multirow{2}{*}{ Material } & $\begin{array}{c}\text { Sample thickness } \\
{[\mathrm{mm}]}\end{array}$ & Sample number \\
\hline \multirow{3}{*}{ TH 550 CA } & 0.155 & 47 \\
\cline { 2 - 3 } & 0.17 & 1 \\
\cline { 2 - 3 } & 0.175 & 83 \\
\hline \multirow{3}{*}{ TH 620 CA } & 0.152 & 90 \\
\cline { 2 - 3 } & 0.17 & 48 \\
\cline { 2 - 3 } & 0.175 & 69 \\
\hline
\end{tabular}




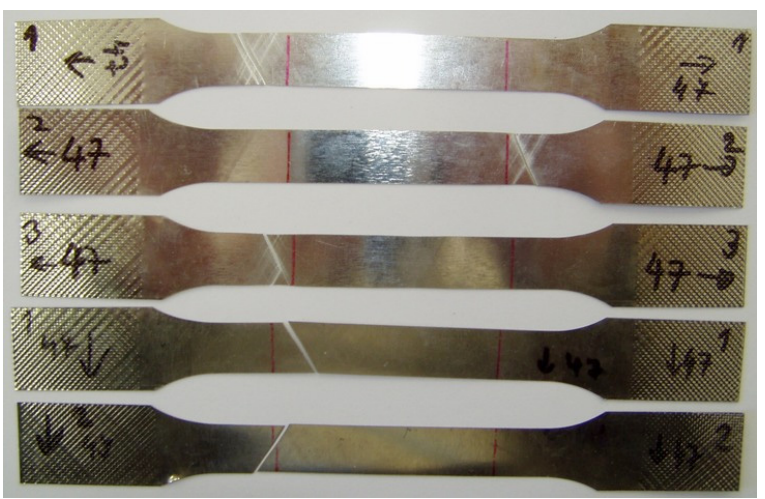

Fig. 1. Specimen after uniaxial tensile test, tested material was TH $550 \mathrm{CA}$, thickness of the material was $0.155 \mathrm{~mm}$

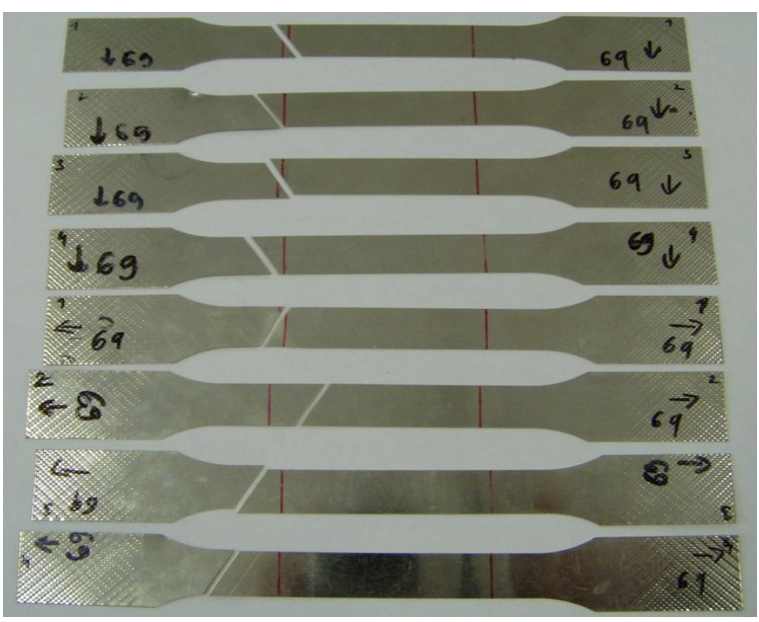

Fig. 2. Specimen after uniaxial tensile test, tested material was TH $620 \mathrm{CA}$, thickness of the material was $0.175 \mathrm{~mm}$

of the test specimen are specified in STN EN 10002-1 + AC1 and STN 42 0321. For tinsteel sheets we often determine the Ultimate tensile strength, Yield strength and ductility of the material. These properties are obtained from uniaxial tensile test. To assess the anisotropic properties of the material, samples were taken in a $0^{\circ}$ and $90^{\circ}$ direction relative to the rolling direction for the tensile test.

In Fig. 1 samples of class TH $550 \mathrm{CA}$ and in Fig. 2 are samples of the class TH $620 \mathrm{CA}$ are presented, both after the uniaxial tensile test. For both of these steels, almost all the samples taken in the rolling direction also samples taken in a direction perpendicular to the rolling direction fractured outside the measured section. The slip spread approximately at an angle of $45^{\circ}$.

\section{BIAXIAL TENSILE TEST - BULGE TEST}

Biaxial tension is one of the most unfavorable types of stress schemes in plastic deformation of steel sheets. That is the reason, why it is suitable to use this type of stress for determination of plastic and mechanical properties of steel sheets. Biaxial hydraulic tensile test, also known as Bulge test is very good for resembling biaxial tension. Fundamentals of this test are shown in Fig. 3.

Measured signals from specimen height sensor and from fluid pressure sensor are processed by technological card and by our own software in graph ,stress - strain“. The record obtained from testing equipment is shown in Fig. 4.,

Biaxial tensile test is based on bulging sheet metal by hydraulic fluid under pressure. Tested sheet is held between bottom plate and die with radius of $40 \mathrm{~mm}$. It is possible to regulate blank holding force by the valve. Specimen flange prevents drawing of the material with the use of bead, which is located in die. Sheet metal is bulged by

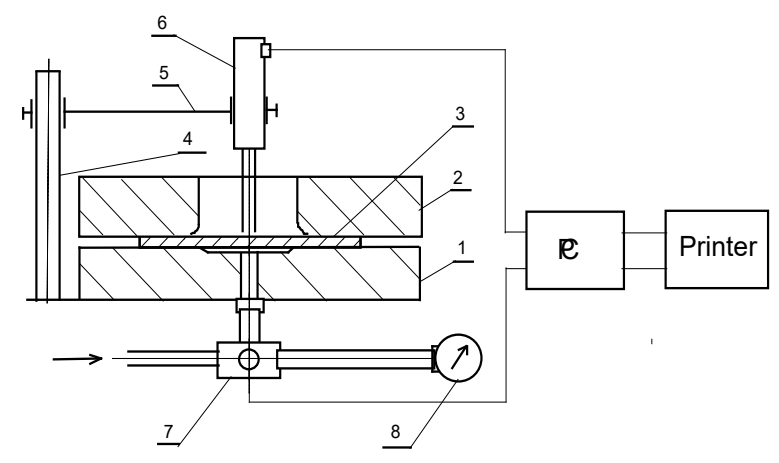

Fig. 3. Principal scheme of Bulge test

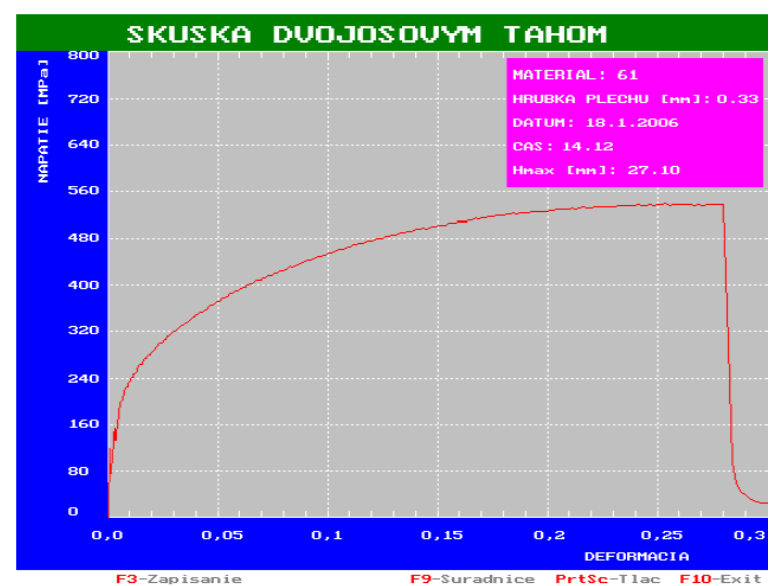

Fig. 4. Graph „Stress - Strain“ obtained from bulge test 


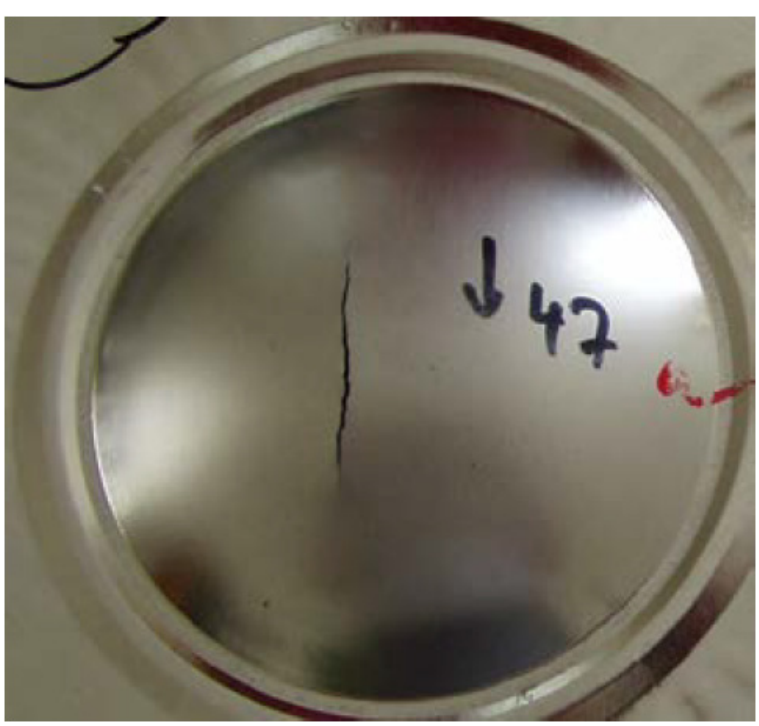

Fig. 5. Specimen N.47 after bulge test, tested material was TH $550 \mathrm{CA}$, with thickness of $0.155 \mathrm{~mm}$

the pressurized hydraulic fluid until specimen is fractured. The height of the fractured bulged specimen, shape of fracture and surface of specimen after fracture is evaluated in this test.

For this test, square specimens with dimension of 130x130 mm were used. Materials were the same as in the uniaxial tensile test (Fig. 5 and Fig 6). From the test, Yield Strength Re, Ultimate tensile strength $\mathrm{Rm}$, bulge height and overall strain was evaluated.

\section{SPRINGBACK TEST}

This test was developed for the purpose of simple determination of the Yield strength of tinsteel sheets while characterizing its certain plastic properties. The test is based on the theoretical basis of elastic and plastic deformation and uses one of the basic laws of the metal forming theory, the law of the presence of elastic deformation at each plastic deformation. The Yield strength values were based on the table recommended by the device manufacturer depending on the springback angle.

A sample of $152.4 \times 25.4 \mathrm{~mm}$ is used to perform the test, which is clamped at one end and the second free end is bent to $180^{\circ}$ about a $25.4 \mathrm{~mm}$ diameter mandrel by means of a roller. The roller returns to the starting position and the springback angle is read off directly on the scale.

Amount of curvature is defined by:

$$
\theta / 180^{\circ}=1-\left(\mathrm{r}_{0}-\mathrm{r}_{1}\right)
$$

where: $\theta$ - springback angle $\left[^{\circ}\right] ; \mathrm{r}_{0}-$ radius of mandrel [mm]; $r_{1}$ - radius of specimen after springback $[\mathrm{mm}]$.

Relationship between $\theta$ a Re is defined by:

$$
\theta / 180^{\circ}=3\left[\left(\mathrm{R}_{\mathrm{e}} \cdot \mathrm{r}\right) /(\mathrm{E} \cdot \mathrm{t})\right]-4\left[\left(\mathrm{R}_{\mathrm{e}} \cdot \mathrm{r}\right) /(\mathrm{E} \cdot \mathrm{t})\right]^{3}
$$

where: Re - Yield Strength $[\mathrm{MPa}], \mathrm{E}-$ Young's modulus $[\mathrm{MPa}], \theta-$ Springback angle $[\mathrm{mm}], \mathrm{r}-$ Bending radius $[\mathrm{mm}], \mathrm{t}-$ Thickness of specimen $[\mathrm{mm}]$.

\section{RESULTS}

Measured results of strength and plastic properties of continuously annealed packaging sheets are shown in Fig 7., 8. and 9. In Fig. 7 the values of Yield strength obtained by uniaxial tensile test, biaxial tensile test (bulge test) and springback test are compared.

It follows from the figure that the measured values of the tensile strength obtained by the uniaxial tensile test for the TH 550 CA grade material are in all samples taken in the rolling direction and in the samples taken in a direction perpendicular to the direction of rolling within the limits of the values recommended by the relevant standard (only specimen N. 47 shown value out of standards limits). For TH 620 CA grade steel, the values of Yield strength obtained by the uniaxial tensile test for all measured samples taken in the rolling direction and in a direction perpendicular to the direction of rolling were in the tolerance specified by the relevant standard.

Values of Yield strength obtained from biaxial tensile test for TH 550 CA grade steel were in the

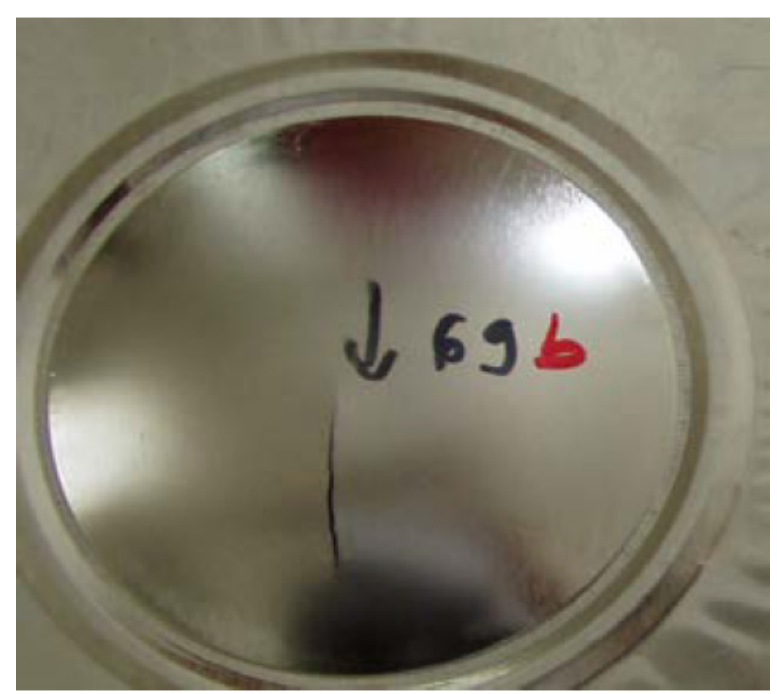

Fig. 6. Tested material TH $620 \mathrm{CA}$, with thickness of $0.175 \mathrm{~mm}$ after bulge test 
tolerance specified by the relevant standard, but values of Yield strength for material TH $620 \mathrm{CA}$ were not in the tolerance specified by the standard. Values of Yield strength obtained from Springback test were within limit of standard for TH 620 CA steel. For TH 550 CA steel, values of Yield strength were over the limit specified by the standard.

In Fig. 8, the values of tensile strength obtained in the uniaxial tensile test and the biaxial tensile test is compared. The measured values in the uniaxial tensile test and values obtained by the biaxial tensile test were within the limits specified by the relevant standard.

A comparison of the ductility of the investigated packaging steel sheets is shown in Fig. 9. It is evident from the figure that the highest values of ductility for both grades were achieved in the biaxial test (except for sample N. 1).

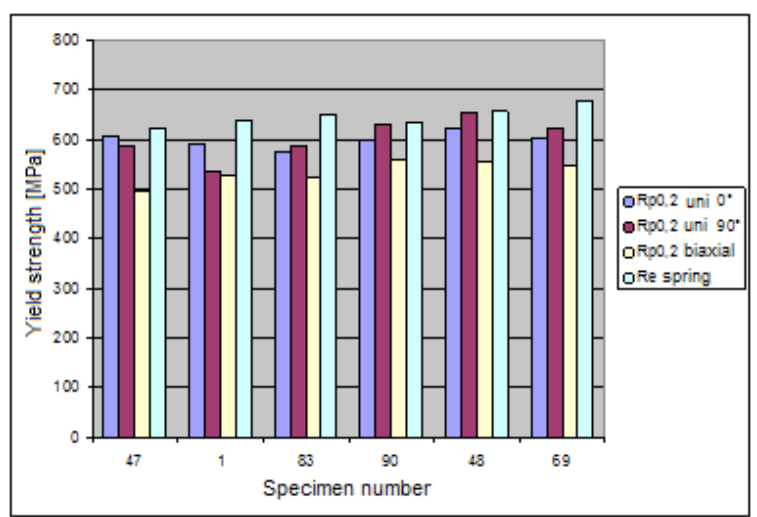

Fig. 7. Comparison of the Yield strength obtained in the uniaxial test in a $0^{\circ}$ and $90^{\circ}$ direction, the Yield strength obtained by the biaxial tensile test and the

Yield strength obtained by the springback test

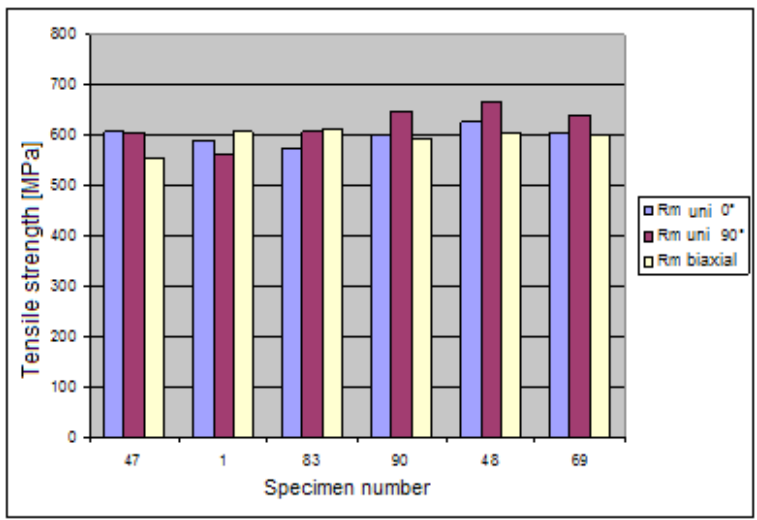

Fig. 8. Comparison of the tensile strength obtained in the uniaxial test in a $0^{\circ}$ and $90^{\circ}$ direction and tensile strength obtained by the biaxial tensile test

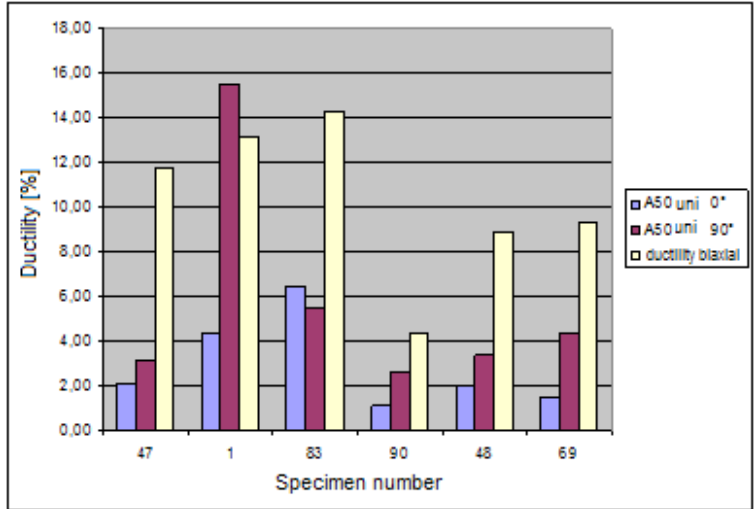

Fig. 9. Comparison of the A50 ductility obtained in the uniaxial test in a $0^{\circ}$ and $90^{\circ}$ direction and the

"ductility" obtained in the biaxial tensile test

\section{CONCLUSIONS}

Based on the experiments, it can be concluded that the strength and plastic properties of the thin packaging sheets determined by the different tests cannot be compared.

The results of the uniaxial tensile test achieve the closest values for Yield strength and tensile strength in terms of the results set by the standard. The ductility values obtained from this test achieve considerable scattering, which is caused, in particular, by fracturing of the samples out of the measured area and locating the plastic deformation without developing the deformation over the entire measuring range.

The Yield strength is lower in the biaxial pull test for all investigated materials than in the uniaxial pull test. This is due to the strain - biaxial tensile stress.

In the springback test, the Yield strength values were the highest. This may be due to an inappropriate mathematical model for determining the Yield strength for these steel sheet grades. For further use of this test, it is necessary to review models for calculating the Yield strength.

\section{Acknowledgements}

The authors are grateful to APVV for support of experimental work under grant APVV-14-0834 and the project VEGA No. 1/0441/17.

\section{REFERENCES}

1. Spišák, E., Slota, J., Majerníková, J.: Hodnotenie anizotropie tenkých obalových plechov. In: Visnik: Naukovo-mechničnij zbirnik. Kijev: Nacional'nij transportnij univrsitet, 2006, p. 23-29. 
2. Majerníková, J.: Medzné deformácie tenkých obalových plechov pri rôznych napät'ovo-deformačných stavoch. Dizertačná práca, Košice, 2008.

3. Spišák, E. - Majerníková, J: Properties evaluation of progressive wrapping materials. In: Mechanical Engineering SI 2008: 12th International Conference: proceedings of papers. Bratislava STU, 2008. ISBN 978-80-227-2982-6. S. 1-8.

4. Spišák, E., Slota, J., Majerníková, J.: Analýza začiatku plastickej deformácie DR obalových plechov. In: Acta Mechanica Slovaca. roč. 10, č. 2b Pro-tech-ma (2006), s. 387-392. ISSN 1335-2393.

5. Spišák, E. - Majerníková, J.: Plastic deformation of tin coated steel sheet under different stress-strain states. In: Progressive technologies and materials. 3-B : Materials. Rzeszów : Oficyna Wydawnica Politechniki Rzeszowskiej, 2009. ISBN 978- 837199-550-7. - P. 25-35.

6. Chongthairungruang, B; Uthaisangsuk, V. Springback prediction in sheet metal forming of high strength steels, Materials and Design 2013, 50, pp. 253-266. 10.1016/j.matdes.2013.02.060.

7. Lei, D; Xinyun, W; Junsong, J; Liangjun, X. Springback and hardness of aluminum alloy sheet part manufactured by warm forming processs using nonisothermal dies, Procedia Engineering 2017, 207, pp. 2388-2393. 10.1016/j.proeng.2017.10.1013.

8. Wagoner, R; H. Lim, H; Lee, M.G.. Advanced Issues in springback, International Journal of Plas- ticity 2013, 45, pp. 3-20. https://doi.org/10.1016/j. ijplas.2012.08.006.

9. Trzepiecinski, T; Lemu, H, G. Effect of Computational Parameters on Springback Prediction by Numerical Simulation, Metals 2017, 7, pp. 380. 10.3390/met7090380.

10. Mulidran, P; Spisak, E; Majernikova, J; Sleziak, T; Gres, M. Influence of forming method and process conditions on springback effect in the sheet metal forming simulation, International Journal of Engineering and Science (IJES) 2017, 6, pp. 62-67. 10.9790/1813-0612016267.

11. Banabic, D. Advanced anistropic yield criteria. In Sheet Metal Forming Processes, 1st edition; Springer Heidelberg Dordrecht, Berlin, Germany, 2010, pp. 76-87, ISBN 978-3-540-88112-4.

12. Jung, J, B; Jun, S; Lee, H,S; Kim, B,M; Lee, M,G; Kim, J,H. Anisotropic Hardening Behaviour and Springback of Advanced High-Strength Steels, Metals 2017, 7, pp. 480. 10.3390/met7110480.

13. Banu M, Takamura M, Hama T, Naidim O, Teodosiu C, Makinouchi A. Simulation of springback and wrinkling in stamping of a dual phase steel rail-shaped part, J Mater Process Technol 2006, pp. 173-178. 10.1016/j.jmatprotec.2005.11.023.

14. Slota, J; Spisak, E. Comparison of the forming-limit diafram (FLD) models for drawing quality (DQ) steel sheets, Metalurgija 44 2005, 4, pp. 249-253. 